\title{
PENERAPAN ERGONOMI DALAM DESAIN KURSI KERJA GUNA MENINGKATKAN PRODUKTIFITAS KERJA KARYAWAN
}

\author{
HM. Kholik', Ayudina Puji Estrima²
}

\begin{abstract}
Evalry Konfeksi is a developing home industry in Tulungagung with woman's attire as it main product. Stitching section plays important role here since most of work activities are centered at this section. One facility that has a great impact is working chair, because with more ergonomic working chair the employees will be able to reduce boredom and fatigue at particular part of their body. This will eventually be able to minimize working time so that there will be an improvement on work output and productivity.

From analysis on the research results upon 20 employees during 7 days of on-site observation, we get an improvement on average work efficiency for each work element by $22.05 \%$. The average working time of each element using the new designed working chair is in fact shorter if compared to those of using the old designed. This reduction is 5.72 minutes/product unit on average, thus there is an improvement on employee's productivity. It can be concluded that using the new designed working chair will be capable in resulting in positive impact on company's output improvement.
\end{abstract}

Key Words: ergonomic, design, efficiency.

\section{PENDAHULUAN}

Saat ini perkembangan teknologi serta industri berjalan dengan begitu pesatnya. Semua ini sudah barang tentu tidak akan terlepas dari tersedianya segala fasilitas produksi / kerja yang menunjang / mendukung proses produksi itu sendiri.

Elvary konveksi adalah suatu home industri yang memproduksi barang-barang kebutuhan sandang, seperti kemeja, mukena ( rukuh ), celana, busana kerja dan sebagainya. Saat ini produk yang dihasilkan oleh Elvary konveksi ini dipasarkan ke daerah Blitar, Tulungagung, Kediri, Nganjuk dan daerah sekitarnya.
Salah satu bagian yang sangat menentukan kualitas produk di perusahaan ini adalah bagian sewing (penjahitan). Dibagian inilah proses produksi dilakukan sampai tercipta produk jadi. Akan tetapi kinerja karyawan bagian ini kurang optimal akibat adanya fasilitas kerja yang kurang sesuai dengan dimensi tubuh karyawannya, sehingga berakibat pada rendahnya produktifitas karyawan itu sendiri. Produktifitas kerja yang rendah ini dipengaruhi oleh posisi bekerja mereka yang cenderung cepat menimbulkan kelelahan fisik sebagai akibat adanya fasilitas kerja yang tidak sesuai dengan dimensi tubuh karyawan tersebut.

Dengan melihat kenyataan inilah maka perlu adanya desain fasilitas kerja yang ergonomis sesuai dengan kondisi / dimensi tubuh karyawan tersebut. 


\section{TINJAUAN PUSTAKA}

\section{Pengertian Ergonomi}

Disiplin ergonomi itu digunakan untuk merancang suatu sistem kerja sehingga orang dapat hidup dan bekerja pada sistem tersebut dengan baik yaitu mencapai tujuan yang diinginkan melalui pekerjaan itu dengan efektif, efisien, aman dan nyaman berdasarkan informasi-informasi mengenai sifat, kemampuan dan keterbatasan manusia itu sendiri. Dengan kata lain bahwa disiplin ilmu ergonomi akan lebih memperhatikan faktor manusia, jadi disini manusia tidak lagi harus menyesuaikan dirinya dengan mesin yang dioperasikan (the man fits to the design) melainkan sebaliknya yaitu mesin/perlengkapan kerja dirancang terlebih dahulu dengan memperhatikan kelebihan dan keterbatasan manusia yang mengoperasikannya (the design fits to the man).(Sritomo $W, 1995: 56$ )

\section{Sedangkan Ernest J.Mc.Cormick} mendekati definisi ergonomi yang disebut sebagai "human factor" dengan dua cara yaitu :

1. Human factor menekankan pada keberadaan manusia dan interaksinya dengan produk, perlengkapan, fasilitas, prosedur dan lingkungan kerjanya sehari-hari.

2. Terdapat dua tujuan "human factor" dengan dua cara yaitu :

Untuk meningkatkan
efisiensi dan efektifitas kerja,

termasuk didalamnya usaha memaksimalkan keselamatan kerja dan meningkatkan produktifitas kerja.

Untuk meningkatkan nilai-nilai kemanusiaan termasuk pengembangan keselamatan kerja pengurangan kelelahan dan ketegangan kerja peningkatan kenyamanan dan kepuasan kerja serta pengembangan kualitas hidup.

Pendekatan human factor adalah aplikasi sistematik dari informasi-informasi yang relevan tentang kemampuan manusia, keterbatasan, karakteristik, kebiasaan, dan motifasi untuk merancang peralatan dan prosedur serta lingkungan kerjanya.

\section{Antropometri}

Dalam melakukan perancangan suatu peralatan/fasilitas kita tidak akan bisa lepas dengan hal-hal tentang dimensi tubuh manusia yang nantinya akan menjadi obyek/]emakai dari hasil rancangan tersebut. Untuk mengetahui dimensi tubuh manusia ini maka dilakukan pengukuran yang dikenal dengan antropometri. Antropometri itu sendiri adalah bagian dari ergonomi dimana secara khusus mempelajari cara pengukuran tubuh yang meliputi dimensi linier, berat, isi, juga daerah ukuran, kekuatan, kecepatan dan aspek-aspek lain dari gerakan tubuh.

Menurut Sritomo Wignjosoebroto (1995 : $62 \& 63)$ pengukuran dimensi tubuh itu sendiri dibedakan dengan dua cara yaitu :

1. Pengukuran dimensi struktur tubuh (static anthropometry) yaitu dimensi tubuh yang diukur dalam berbagai posisi standart dan tidak bergerak (tetap tegak sempurna) 
2. Pengukuran dimensi fungsional tubuh (dynamic anthropometry) yaitu pengukuran yang dilakukan terhadap posisi tubuh pada saat berfungsi melakukan gerakangerakan tertentu yang berkaitan dengan kegiatan yang harus diselesaikan.

Pengukuran antropometri pada dasarnya adalah pengukuran jarak antara dua titik pada tubuh manusia yang ditentukan terlebih dahulu sesuai dengan kebutuhan dalam perancangan fasilitas kerja dengan kebutuhan dalam perancangan fasilitas kerja dengan menggunakan suatu alat ukur yang dinamakan antropometer yang dirancang secara khusus untuk mengetahui ukuranukuran tubuh manusia atau juga bisa juga digunakan alat ukur standart.

\section{Pengaruh Keterbatasan Manusia Dalam Melakukan Perancangan}

Manusia sebagai mahkluk yang paling sempurna banyak memiliki kemampuan / kelebihan yang dapat diandalkan akan tetapi dibalik itu semua sebenarnya manusia memiliki banyak keterbatasan baik itu dari segi fisik ataupun psikologisnya. Padahal dalam melakukan aktifitasnya sehari-hari manusia bukan saja mengandalkan kemampuan fisiknya saja akan tetapi juga dipengaruhi oleh faktor psikologisnya (emosional). Sehingga disini perlu adanya penekanan beban mental agar dapat meningkatkan efektifitas kerjanya.
Berkenaan dengan hal itu konsep dasar perancangan kerja yang ergonomis yang dapat diberikan antara lain adalah sebagai berikut :

- Manusia memiliki keragaman bentuk postur tubuh.

- Tingkat pendidikan semakin lama semakin tinggi.

- Perkembangan teknologi semakin pesat dan canggih.

- Adanya spesialisasi kerja.

- Adanya keterkaitan antara pekerjaan satu dengan yang lainnya.

Dengan melihat kenyataan tersebut diatas maka yang harus dilakukan sebelum melakukan perancangan sistem kerja / perlengkapan kerja yang ergonomis, ada beberapa prinsip perancangan yang harus diperhatikan yaitu :

- Perancangan harus disesuaikan dengan pengguna / yang akan mengoperasikan produk tersebut.

口 Meminimalkan presentase yang berada di luar sistem.

• Desain kerja harus memberikan kenyamanan bagi penggunanya.

a Lebih mengutamakan akan pentingnya komunikasi.

a Gunakan alat untuk memperbesar kemampuan manusia.

Dengan memperhatikan prinsip-prinsip perancangan tersebut di atas diharapkan akan dapat diciptakan / dibuat suatu desain yang memperhatikan faktor kemampuan dan keterbatasan manusia yang memiliki berbagai variasi / keragaman antar individu. 


\section{Perancangan Kursi Kerja}

Didalam

melakukan perancangan kursi kerja harus tetap memperhatikan kegiatan / jenis pekerjaan itu sendiri. Dan faktor yang tidak kalah pentingnya adalah dimensi tubuh dari operatornya sendiri yaitu yang berkaitan dengan gaya yang dibutuhkan, pandangan mata, posisi kerja sesuai dengan postur tubuhnya. Kursi yang dirancang itupun harus disesuaikan dengan kondisi dan posisi meja yang biasa digunakan oleh operator tersebut.

Disamping itu dalam melakukan desain kursi kerja juga harus mempertimbangkan kegunaan dari kursi itu sendiri juga harus dipertimbangkan adalah pekerjaan yang dilakukan dalam pemakaian kursi kerja tersebut. Sedangkan dalam melakukan desain terhadap kursi kerja tersebut harus diperhatikan beberapa kriteria diantaranya :

1) Tinggi kursi sebaiknya dirancang sesuai dengan ketinggian alas duduk dari operator yang akan menggunakannya. Hal ini penting karena ukuran kursi yang tidak tepat akan berakibat kurang baik terhadap pemakainya baik dari segi desain maupun kesehatan, yang akan dapat mengakibatkan sirkulasi darah terganggu dan kaki cepat lelah.

2) Dari segi kekuatan sebaiknya kursi kerja dirancang sedemikian rupa agar kuat dan serasi dengan menekankan kekuatan pada bagian-bagian yang mudah retak dan sebaiknya dilengkapi dengan sistem mur baut ataupun keling pasak.

3) Sandaran punggung (belakang) ini akan membantu dalam menjaga keseimbangan posisi duduk. Dalam pendesainan diharapkan sedapat mungkin sandaran punggung ini disesuaikan / mendekati kontur tulang belakang. Sandaran punggung ini didasarkan pada ukuran lebar punggung dengan faktor kelonggaran tertentu.

4) Ketinggian sandaran punggung disesuaikan dengan ukuran tinggi siku duduk dengan persentile $95 \%$.

5) Lebar kursi ditentukan dengan maksud untuk memberikan penyangga pada pinggul sehingga perlu dibuat agak lebar untuk memberikan perasaan nyaman pada pemakainya. Lebar kursi ini diukur dari tepi pinggul ke tepi lainnya dengan menambah kelonggaran dari ketebalan pakaian.

6) Panjang alas duduk diharapkan tidak mengganggu / menghambat aktifitas yang dilakukan oleh pengguna kursi.

7) Bahan yang digunakan dalam desain kursi ini diharapkan adalah bahan yang mudah dibentuk sesuai dengan desain yang telah dirancang disamping itu bahan juga harus yang mudah didapatkan, tetapi juga harus tetap diperhatikan faktor kekuatannya. Untuk tempat duduk dan sandaran punggung sedapat mungkin diberi material yang cukup lunak dengan harapan dapat mengurangi kelelahan / menghambat segera munculnya rasa lelah dan capek. 


\section{Akibat Yang Ditimbulkan Dari Desain \\ Kursi Yang Tidak Ergonomis}

Desain kursi yang tidak sesuai dengan dimensi tubuh pemakainya (tidak ergonomis) akan membawa pengaruh yang kurang baik bagi pemakainya itu sendiri yang pada akhirnya akan berpengaruh pada efektifitas dan efisiensi kerja mereka. Akibat dari desain kursi yang tidak ergonomis ini antara lain :

1. Alas kursi yang terlalu pendek akan menimbulkan tekanan pada pertengahan paha

2. Sebaliknya jika alas tempat duduk yang terlalu panjang juga tidak ergonomis karena berakibat adanya tekanan pada pertemuan betis dan paha atau lipatan lutut sehingga hal ini akan memberikan ketidaknyamanan pada pemakainya

3. Apabila alas tempat duduk terlalu rendah akan menimbulkan kelelahan pada tungkai sehingga cenderung mendorong badan ke belakang yang berakibat timbulnya tekanan pada pinggang

4. Alas tempat duduk yang terlalu tinggi juga tidak baik bagi pemakainnya karena hal ini mengakibatkan tekanan pada telapak kaki

\section{METODOLOGI PENELITIAN}

Data antropometri disini diperoleh dari pengukuran langsung pada karyawan di bagian penjahitan dengan sampel sebanyak 20 karyawan dan semuanya adalah wanita.

\section{Uji Keseragaman Data}

Guna mengetahui apakah sampel data hasil pengamatan mempunyai keseragaman data dalam arti tidak terdapat data ekstrim, maka hal ini dapat diketahui dari uji keseragaman data. Rumus uji keseragaman data yang dipakai disini adalah

$$
\begin{aligned}
& \mathrm{BKA}=\overline{\mathrm{X}}+\mathrm{k} \cdot \mathrm{SD} \\
& \mathrm{BKB}=\overline{\mathrm{X}}-\mathrm{k} \cdot \mathrm{SD}
\end{aligned}
$$

Dimana :

$$
\begin{aligned}
& \mathrm{X}: \text { rata-rata hasil pengukuran } \\
& \mathrm{SD}: \text { Standart Deviasi } \\
& \mathrm{k}: \text { harga indeks besarnya tergantung } \\
& \text { tingkat kepercayaan yang digunakan }(95 \% \\
& \mathrm{k}=3 ; 95 \% \mathrm{k}=2 ; 68 \% \mathrm{k}=1)
\end{aligned}
$$

\section{Uji Kecukupan Data}

Uji kecukupan data disini dilakukan setelah uji keseragaman data dimana hal ini untuk mengetahui apakah data yang sudah seragam dianggap masih cukup untuk dilakukan perhitungan selanjutnya. Rumus yang digunakan adalah :

$$
N^{\prime}=\left[\frac{k \sqrt{N\left(\sum x^{2}\right)-\left(\sum x\right)^{2}}}{s \cdot \sum x}\right]^{2}
$$




\section{Perhitungan Dan Penetapan persentile}

Nilai persentile ini nantinya akan digunakan sebagai dasar menetapkan ukuran kursi kerja baru. Adapun rumus yang digunakan adalah sebagai berikut

$$
\begin{aligned}
& P_{5}=B+\left[\frac{\frac{5 n}{100}-f}{f_{m}-f}\right] \times i \\
& P_{50}=B+\left[\frac{\frac{50 n}{100}-f}{f_{m}-f}\right] \times i \\
& P_{95}=B+\left[\frac{\frac{95 n}{100}-f}{f_{m}-f}\right] \times i
\end{aligned}
$$

\section{Pengujian Hipotesis}

Prosedur pengujian dua rataan jika standatr deviasi populasi rata-rata waktu kerja untuk kedua desain tidak sama dan tidak diketahui dengan $\quad n_{1}$ $=\mathrm{n}_{2}=\mathrm{n}$, berdasarkan buku Statistik For Engineering And The Science (William MendenHall ) adalah sebagai berikut :

Hipotesa

$$
\begin{aligned}
& \mathrm{H}_{0}: \mu_{1}=\mu_{2} \\
& \mathrm{H}_{1}: \mu_{1} \neq \mu_{2}
\end{aligned}
$$

Nilai tabel kurva distribusi t ( untuk $\alpha=0.05, \mathrm{v}=12$ ) adalah 2.179.

Dimana : $\mathrm{t}_{\alpha / 2}=0.025$

$$
\mathrm{v}=\left(\mathrm{n}_{1}+\mathrm{n}_{2}-\right.
$$

2) $=7+7-2=12$

a Nilai t hitung

Digunakan rumus :

$$
\mathrm{t}=\frac{\left(\overline{\mathrm{X}}_{1}-\overline{\mathrm{X}}_{2}\right)-\text { do }}{\sqrt{\left(\mathrm{S}_{1}^{2} / \mathbf{n}_{1}\right)+\left(\mathrm{S}_{2}{ }^{2} / \mathrm{n}_{2}\right)}}
$$

Kesimpulan

Jika $t_{\text {hitung }}>t_{\text {tabel }}$ maka $\mathrm{H}_{0}$ ditolak dan $\mathrm{H}_{1}$ diterima

Jika $\mathrm{t}_{\text {hitung }}<\mathrm{t}_{\text {tabel }}$ maka $\mathrm{H}_{0}$ diterima dan $\mathrm{H}_{1}$ ditolak $\mathrm{H}_{0}$ ditolak dan $\mathrm{H}_{1}$ diterima artinya :

Rata-rata waktu kerja untuk tiap. elemen kerja dengan menggunakan kursi kerja baru lebih cepat secara signifikan jika dibandingkan desain lama sehingga dapat meningkatkan efisiensi kerja karyawan.

$\mathrm{H}_{0}$ diterima dan $\mathrm{H}_{1}$ ditolak artinya :

Rata-rata waktu kerja untuk tiap elemen kerja dengan menggunakan kursi kerja baru tidak lebih cepat secara signifikan jika dibandingkan desain lama sehingga tidak dapat meningkatkan efisiensi kerja karyawan

\section{HASIL DAN PEMBAHASAN}

Dari pengukuran waktu kerja sebelum dan ketika eksperimen terhadap desain kursi kerja baru di lapangan, diperoleh hasil analisa seperti pada tabel 1 di bawah ini :

Tabel 1

Rata-rata waktu kerja sebelum dan sesudah perbaikan desain kursi kerja

\begin{tabular}{|c|c|c|c|}
\hline \multirow{2}{*}{ Elemen } & \multicolumn{2}{|c|}{$\begin{array}{c}\text { Waktu Kerja } \\
\text { (menit) }\end{array}$} & \multirow{2}{*}{ Penurunan } \\
\cline { 2 - 4 } & $\begin{array}{c}\text { Desain } \\
\text { Lama }\end{array}$ & $\begin{array}{c}\text { Desain } \\
\text { Baru }\end{array}$ & \\
\hline I & 15.60 & 14.47 & 1.13 \\
II & 15.55 & 14.52 & 1.03 \\
III & 5.69 & 4.25 & 1.44 \\
IV & 3.69 & 2.54 & 1.15 \\
V & 6.60 & 5.67 & 0.97 \\
\hline
\end{tabular}

Penurunan waktu kerja ini disebabkan adanya perubahan posisi kerja sehingga pekerja lebih optimal menggunakan waktunya karena 
waktu yang biasanya terbuang percuma hanya untuk melepas lelah akibat posisi kerja yang kurang ergonomis dapat diminimalkan.

\section{Analisa Data Allowance}

\section{Tabel 2}

Perbandingan faktor alowance sebelum dan sesudah perbaikan desain kursi kerja

\begin{tabular}{|c|c|c|c|}
\hline \multirow{2}{*}{$\begin{array}{c}\text { Elemen } \\
\text { Kerja }\end{array}$} & $\begin{array}{c}\text { \% Alowance } \\
\text { Desain } \\
\text { Lama }\end{array}$ & $\begin{array}{c}\text { Desain } \\
\text { Baru }\end{array}$ & \\
\hline I & 16.85 & 10.10 & 6.75 \\
II & 18.55 & 11.00 & 7.55 \\
III & 14.60 & 10.37 & 4.23 \\
IV & 13.65 & 8.15 & 5.50 \\
V & 13.60 & 8.04 & 5.56 \\
\hline
\end{tabular}

Dengan adanya desain baru menyebabkan kenyamanan pada operator, sehingga kelonggaran (allowance) yang diperlukan lebih sedikit daripada sebelumnya.Waktu kerja yang biasanya terbuang untuk melepas lelah menjadi lebih kecil.

\section{Analisa Data Waktu Normal}

\section{Tabel 3}

Perbandingan rata-rata waktu normal sebelum dan sesudah perbaikan desain kursi kerja

\begin{tabular}{|c|c|c|c|}
\hline \multirow{2}{*}{ Elemen } & \multicolumn{2}{|c|}{$\begin{array}{c}\text { Waktu Normal } \\
\text { (menit) }\end{array}$} & \multirow{2}{*}{ Penurunan } \\
\cline { 2 - 3 } & $\begin{array}{c}\text { Desain } \\
\text { Lama }\end{array}$ & $\begin{array}{c}\text { Desain } \\
\text { Baru }\end{array}$ & \\
\hline I & 17.60 & 17.17 & 0.43 \\
II & 17.60 & 17.54 & 0.06 \\
III & 6.50 & 5.00 & 1.50 \\
IV & 4.26 & 3.01 & 1.25 \\
V & 7.45 & 6.59 & 0.86 \\
\hline
\end{tabular}

\section{Analisa Data Waktu Standart}

Tabel 4

Perbandingan rata-rata waktu standart sebelum dan sesudah perbaikan desain kursi kerja

\begin{tabular}{|c|c|c|c|}
\hline \multirow{2}{*}{ Elemen } & \multicolumn{2}{|c|}{$\begin{array}{c}\text { Waktu Sandart } \\
\text { (menit) }\end{array}$} & \multirow{2}{*}{ Penurunan } \\
\cline { 2 - 3 } & $\begin{array}{c}\text { Desain } \\
\text { Lama }\end{array}$ & $\begin{array}{c}\text { Desain } \\
\text { Baru }\end{array}$ & \\
\hline I & 21.12 & 19.10 & 2.02 \\
II & 21.65 & 19.71 & 1.94 \\
III & 7.61 & 5.57 & 2.04 \\
IV & 4.94 & 3.28 & 1.66 \\
V & 8.64 & 7.16 & 1.48 \\
\hline
\end{tabular}

\section{Analisa Data Output Standart}

\section{Tabel 5}

Perbandingan rata-rata output standart sebelum dan sesudah perbaikan desain kursi kerja

\begin{tabular}{|c|c|c|c|}
\hline \multirow{2}{*}{ Elemen } & \multicolumn{2}{|c|}{$\begin{array}{c}\text { Output Standart } \\
\text { Kerja }\end{array}$} & \multirow{2}{*}{ Peningkatan $/$ jam $)$} \\
\cline { 2 - 3 } & $\begin{array}{c}\text { Desain } \\
\text { Lama }\end{array}$ & $\begin{array}{c}\text { Desain } \\
\text { Baru }\end{array}$ & \\
\hline I & 3 & 4 & 1 \\
II & 3 & 4 & 1 \\
III & 9 & 11 & 2 \\
IV & 12 & 19 & 7 \\
V & 8 & 9 & 1 \\
\hline
\end{tabular}

Peningkatan output standart disini karana adanya penurunan waktu standart untuk tiap elemen kerja yang akhirnya juga akan meningkatkan tingkat efisiensi kerja karyawan.

\section{Analisa Data Tingkat Efisiensi}

Tingkat efisiensi sebelum dan sesudah adanya perbaikan ini akan berpengaruh terhadap produktyifitas karyawan. Nilai tingkat efisiensi dapat dilihat dibawah ini : 
Tabel 6

Perbandingan tingkat efisiensi sebelum dan sesudah perbaikan desain kursi kerja

\begin{tabular}{|c|c|c|c|}
\hline \multirow{2}{*}{ Elemen } & \multicolumn{2}{|c|}{$\begin{array}{c}\text { Tingkat Efisiensi } \\
\text { (\%) }\end{array}$} & \multirow{2}{*}{ Peningkatan } \\
\cline { 2 - 3 } & $\begin{array}{c}\text { Desain } \\
\text { Lama }\end{array}$ & $\begin{array}{c}\text { Desain } \\
\text { Baru }\end{array}$ & \\
\hline I & 50 & 56.25 & 6.25 \\
II & 50 & 58.93 & 8.93 \\
III & 17.86 & 20.45 & 2.59 \\
IV & 11.95 & 11.89 & -0.06 \\
V & 20.66 & 25.00 & 4.34 \\
\hline
\end{tabular}

membukltikan bahwa desain kursi kerja usulan / baru akan lebih produktif jika dibandingkan dengan desain kursi kerja lama.

\section{KESIMPULAN}

Berdasarkan pembahasan masalah dan analisa dari hasil pengolahan data maka dapat disimpulkan bahwa :

1. Ketidakergonomisan desain kursi kerja lama terletak pada :

\ Bahan alas duduk dari besi sehingga cepat menimbulkan kelelahan dan rasa panas juga ukurannya yang sempit, seharusnya alas duduk dari bahan yang empuk dengan ukuran panjang $37.6 \mathrm{~cm}$ dan lebar $45.07 \mathrm{~cm}$ sesuai dengan dimensi tubuh karyawan

a Tidak terdapatnya sandaran pada kursi sehingga menyebabkan pekerja cepat lelah terutama pada bagian punggung, hal ini menyebabkan pekerja sering istirahat hanya sekedar untuk melepas lelah dan akibatnya waktu kerja mereka banyak yang terbuang sia-sia.

2. Output actual desain lama sebanyak 150 produk/hari,dengan adanya desain baru maka terjadi penurunan waktu kerja dan faktor allowance sehingga - output produksinya menjadi 225 produk/hari sehingga peningkatannya sebesar 75 produk/hari

3. Adanya peningkatan rata-rata nilai efisiensi kerja sebesar $22.05 \%$ jika dibandingkan saat menggunakan desain kursi kerja lama dan hal ini menunjukkan adanya peningkatan produktifitas kerja karyawan.

4. Pengujian dengan statistik uji t dengan dua rataan (dengan asumsi $\quad \sigma_{1} \neq \sigma_{2}$ dan tidak diketahui ) menunjukkan bahwa waktu kerja untuk tiap elemen kerja dengan menggunakan desain kursi kerja baru lebih cepat secara signifikan dibandingkan dengan menggunakan desain lama. Penurunan waktu kerja disini sebesar 5.72 menit dan ini menunjukkan desain kursi kerja baru lebih produktif dibandingkan desain lama.

\section{DAFTAR PUSTAKA}

Eko Nurmianto,1996 Ergonomi Konsep Dasar dan Aplikasinya. Guna Widya.Jakarta

Julius Panero, Martin Zelnik. 1980 Human

Demension And Interior Space.The Architecture Press Ltd.London

Mendenhall William dkk.1992 Statistic For Engineering And The Science. Singapore. 
Sritomo Wignjsoebroto, 1995 Ergonomi Studi Gerak dan Waktu.Guna Widya Jakarta.

Sanders Mark S,Mc.Cormiec E.J.1987,

Human Faktor in Engineering and Design.Sixth Edition. MC Graw Hill.Singapore.

Walpole Ronald.1995, Pemgantar

Statistika.Gramedia Pustaka

Utama. Jakarta 